\title{
HUBUNGAN MEKANISME KOPING DENGAN TINGKAT KECEMASAN LANSIA PADA MASA PANDEMI COVID-19 DI WILAYAH KERJA PUSKESMAS REJOSARI PEKANBARU
}

\author{
${ }^{1 *}$ Awaliyah Ulfah Ayudytha; ${ }^{2}$ Abdurrahman Hamid; ${ }^{3}$ Arlina Waruwu \\ ${ }^{1,3}$ Sekolah Tinggi Ilmu Kesehatan Pekanbaru Medical Center \\ ${ }^{2}$ Sekolah Tinggi Hangtuah Pekanbaru \\ *e-mail: ditarhmn@gmail.com
}

Diterima : November 2021, Diterbitkan Desember 2021

\begin{abstract}
ABSTRAK
Corona Virus Disease (Covid-19) adalah penyakit menular yang dapat ditularkan dari seseorang yang positif Covid-19 melalui percikan cairan dari mulut atau hidung saat batuk dan bersin. Covid-19 ini sudah menimbulkan kecemasan di kalangan masyarakat puskesmas rejosari pekanbaru khususnya lanjut usia yang sangat rentan kepada penularan penyakit ini. Kecemasan merupakan kekhawatiran dan rasa takut yang intens, berlebihan, dan terus-menerus sehubungan dengan situasi sehari-hari. Dapat terjadi hal-hal seperti jantung berdenyut kencang, napas tersengal- sengal, berkeringat, dan merasa lelah. Penelitian bertujuan untuk melihat apakah ada hubungan mekanisme koping dengan tingkat kecemasan lansia di wilayah kerja puskesmas Rejosari Pekanbaru. Desain penelitian yang di gunakan adalah deskriprif korelasi dengan rancangan Cross Sectional Study.Jumlah responden dalam penelitian ini adalah 45 responden dengan teknik sampling accidental sampling. Alat ukur yang digunakan adalah Kuesioner Jalowiec Coping Scale dan Kuesioner STAI (State- Trait Anxiety Inventory) Hasil Penelitian didapatkan bahwa mekanisme koping lansia dalam kategori adaptif dengan 36 (80.0\%) . Sementara pada tingkat kecemasan lansia terdapat dalam kecemasan ringan 29 responden $(64,4 \%)$ Penelitian ini merupakan penelitian kuantitatif dengan menggunakan desain penelitian Deskriptif Korelasi. Penelitian ini menggunakan rancangan Cross Sectional Study Berdasarkan hasil dari uji chi-square diproleh $\mathrm{p}$ value mekanisme koping $=0.035$ lebih kecil daripada nilai alpha $(\mathrm{p}<0.050)$, yang menunjukkan adanya hubungan yang signifikan antara Mekanisme Koping dengan Tingkat Kecemasan
\end{abstract}

Kata Kunci : Mekanisme Koping, Tingkat Kecemasan, Covid-19, Lansia

\begin{abstract}
Corona Virus Disease (Covid-19) is an infectious disease that can be transmitted from someone who is positive for Covid-19 through fluids from the mouth or nose when coughing and sneezing. This Covid-19 has caused anxiety among the people of the Rejosari Pekanbaru Health Center, especially the age who is very vulnerable to the transmission of this disease. Anxiety is an intense, excessive, and persistent creation and fear associated with everyday situations. Things like racing heart, shortness of breath, feeling sensations, and feeling tired can occur. This study aims to see whether there is a relationship between coping mechanisms and anxiety in the working area of the Rejosari Public Health Center Pekanbaru. The research design used was descriptive correlation with a cross sectional study design. The number of respondents in this study was 45 respondents with accidental sampling technique. The measuring instrument used is the Jalowiec Coping Scale Questionnaire and the STAI (State-Trait Anxiety Inventory) Questionnaire. The results showed that the coping mechanisms of the elderly were in the adaptive category with 36 (80.0\%). Meanwhile, at the level of anxiety in mild anxiety 29 respondents (64.4\%) This research is a quantitative study using a descriptive correlation research design. This study uses a cross sectional study design. Based on the results of the chi-
\end{abstract}


square test, the $p$ value of the coping mechanism $=0.035$ is smaller than the alpha value ( $p<$ 0.050), which indicates a significant relationship between coping mechanisms and anxiety levels. Keywords: Coping mechanism, Anxiety Level, Covid-19, Elderly

\section{PENDAHULUAN}

Kecemasan merupakan kondisi perubahan pada sikap yang lebih emosional dalam segala bentuk keadaan. Gangguan kecemasan terjadi adanya ketidakseimbangan neurotransmitter serotonin, norepiefrin dan GABA yang menjadi penyebab dari kecemasan, kecemasan bisa juga diartikan seperti alarm dalam tubuh. Kecemasan dapat dialami pada semua usia, namun realitanya lanjut usia lebih sering mengalami kecemasan (Annisa, D 2016).

Kecemasan memiliki karakteristik berupa munculnya perasaan takut, kehati-hatian dan kewaspadaan yang tidak jelas dan tidak menyenangkan. Gangguan kecemasan merupakan sebuah gangguan yang ditandai oleh kecemasan, kekhawatiran yang berlebihan, kesulitan mengendalikan gejala ini, dan secara klinis menunjukkan tandatanda penderitaan dan kekacauan yang signifikan dan cukup serius untuk menyebabkan gangguan dalam kehidupan seseorang (Annisa, D 2016).

Saat ini masalah kesehatan yang sangat mempengaruhi banyak aspek adalah kejadian Corona Virus sisease 2019 (Covid-19). Penyakit yang disebabkan oleh virus ini telah menjadi pandemi. Pandemi Covid-19 telah mengubah seluruh segi kehidupan masyarakat. Tidak terkecuali para orang tua yang rentan. Efek psikososial cenderung bertahan lebih lama dibandingkan pandemi itu sendiri. Isolasi selama beberapa bulan menimbulkan kejenuhan, kecemasan, bahkan insomnia. Awal mula terjadinya infeksi saluran napas akibat virus ini ada di Wuhan pada bulan Desember 2019.

Berdasarkan Data dari Badan Satuan Tugas Penanganan Covid-19 pada tanggal 2 februari 2021 data terkonfirmasi secara global sebanyak 102.817.575 sedangkan kasus Kematian 2.227.420. Covid-19 di Indonesia data yang terkonfirmasi pada tanggal 2 Februari sebanyak 1.099.687 Positif, 89.530 kasus yang sembuh, 30.581 kasus yang meninggal. Dilaporkan dari 34 Provinsi di Indonesia salah satunya yaitu Provinsi DKI Jakarta dengan kasus tertinggi 273.332 $(25,1 \%)$. Sedangkan di Provinsi Riau dilaporkan kasus sebanyak 29,029 (2.7\%). Dengan kasus tertinggi di Pekanbaru sebanyak 13.644, Kasus yang yang sembuh 12.679, sedangkan kasus meninggal 30 kasus. (Satuan Tugas Penanggana Covid-19. 2021)

Mereka yang tidak memiliki keluarga atau teman dekat, dan bergantung pada dukungan layanan sukarela atau perawatan sosial, yang sebelumnya sudah merasakan kesepian, terisolasi, atau terpencil, menghadapi hambatan lebih lanjut karena pembatasan kontak sosial (Akbar 2021) Hal ini secara tidak langsung memberikan gambaran bahwa pembatasan konta lanjut usia hingga mengakibatkan munculnya masalah kecemasan pada lansia sosial karena pandemi Covid-19 dapat mempengaruhi tingkat

Upaya untuk mengatasi masalah kecemasan pada lansia yaitu dibutuhkan koping individu yang baik. Mekanisme koping pada dasarnya adalah mekanisme pertahanan diri terhadap perubahan yang terjadi baik dari dalam maupun dari luar. Mekanisme koping adalah cara yang dilakukan individu dalam menyelesaikan masalah, menyesuaikan diri dengan perubahan, serta respon terhadap situasi yang mengancam.

Mekanisme koping dikategorikan menjadi dua, yaitu koping berfokus pada masalah (problem focused coping) dan koping berfokus pada emosi (emotion focused coping). Mekanisme Koping dilakukan individu untuk menangani masalah dan menyeimbangkan emosi dalam situasi yang menekan. Penanganan masalah tersebut 
mencakup semua hal yang dipikirkan atau dilakukan seseorang dalam usaha menyesuaikan diri dengan stres, dengan memilih strategi yang paling sesuai serta menuntut evaluasi yang berkesinambungan dalam hubungan mereka dengan lingkungan (Annisa. 2016).

Tujuan dari Penelitian ini adalah untuk mengetahui apakah ada hubungan mekanisme koping dengan tingkat kecemasan lansia pada masa pandemi Covid-19 di wilayah kerja Puskesmas Rejosari Pekanbaru

\section{METODE PENELITIAN}

Penelitian ini merupakan penelitian kuantitatif dengan menggunakan desain penelitian Deskriptif Korelasi. Deskriptif Korelasi adalah penelitian yang menelaah hubungan antara dua variabel pada suatu situasi atau sekelompok subjek (Notoatmodjo, 2012). Penelitian ini menggunakan rancangan Cross Sectional Study. penelitian dimulai dari persiapan penelitian dimulai dari bulan Desember 2020 sampai bulan Juni 2021d di wilayah kerja Puskesmas Rejosari Pekanbaru. Populasi dan subjek penelitian adalah lansia berjumlah 45 orang di wilayah kerja Puskesmas Rejosari Pekanbaru.

Teknik sampling dalam penelitian ini menggunakan teknik purposive sampling yaitu teknik untuk menentukan sampel penelitian dengan beberapa pertimbangan tertentu yang bertujuan agar data yang diperoleh nantinya bisa lebih representatif. Pada penelitian yang menjadi Sampel adalah 45 orang lansia.

Dalam penelitin ini terdapat variabel bebas (Indenpenden) Variabel ini biasanya diamati untuk diketahui hubungannya dengan variabel lain adalah mekanisme koping dengan Alat ukur Kuesioner (Jalowiec Coping Scale). Dengan menggunakan skala ukur ordinal dengan skor penilaian 1.Mal adaptif : 25-61 2.Adaptif 62-100. Variabel terikat (Dependen) adalah variabel yang dipengaruhi oleh variabel bebas. (Donsu, 2016). Variabel terikat dalam penelitian ini adalah tingkat kecemasan lansia pada masa pandemi Covid-
19. Dengan Alat Ukur Kuesioner STAI (StateTrait Anxiety Inventory) dengan menggunakan skala ordinal dengan skor penilaian 1. Kecemasan ringan: 20-39 2. Kecemasan Sedang :40-59 3. Kecemasan berat: 60- 80 (McDowell,2006).

\section{HASIL PENELITIAN}

Tabel 1. Distribusi Frekuensi Karakteristik Lansia di Wilayah Kerja Puskesmas Rejosari Pekanbaru Tahun 2021

\begin{tabular}{|c|c|c|c|}
\hline so & Karakteristik & Jumlah & Perseutase \\
\hline T & $\begin{array}{l}\text { Cmar: } \\
\text { a. } 60-70 \\
\text { b. } 71-80\end{array}$ & $\begin{array}{c}39 \\
6\end{array}$ & $\begin{array}{l}86,7 \\
13,3\end{array}$ \\
\hline 2 & $\begin{array}{l}\text { Jeais Kelamin: } \\
\text { a Laki-laki } \\
\text { b. Perempuan }\end{array}$ & $\begin{array}{l}16 \\
29\end{array}$ & $\begin{array}{l}35,6 \\
64,6\end{array}$ \\
\hline 3 & $\begin{array}{l}\text { Penctidikan Terakchir : } \\
\text { a. SD } \\
\text { b. SMIP } \\
\text { c. SMLA } \\
\text { d. Perguruan Tingei }\end{array}$ & $\begin{array}{c}21 \\
15 \\
7 \\
2\end{array}$ & $\begin{array}{c}46,7 \\
33,7 \\
15,6 \\
4,4\end{array}$ \\
\hline & Tetal & 45 & 100 \\
\hline
\end{tabular}

responden $(86,7 \%)$. Mayoritas jenis kelamin lansia adalah Perempuan sebanyak 29 responden $(64,4 \%)$. Mayoritas pendidikan terakhir lansia mempunyai tingkat pendidikan SD sebanyak 21 responden $(46,7 \%)$

Tabel 2. Distribusi Frekuensi Mekanisme Koping dan Tingkat Kecemasan Lansia di Wilayah Kerja Puskesmas Rejosari Pekanbaru Tahun 2021

\begin{tabular}{lccc}
\hline No & Karaterisik & Frekuensi & Presentase (\%) \\
\hline 1 & Mekanisme Koping: & & \\
& a. Adaptif & 36 & 80,0 \\
& b. Maladaptif & 9 & 20,0 \\
\hline 2 & Tingkat Kecemasan: & & \\
& a. Kecemasan Ringan & 29 & 64,4 \\
& b. Kecemasan Sedang & 13 & 28,9 \\
& c. Kecemasan Berat & 3 & 6,7 \\
\hline
\end{tabular}

Berdasarkan tabel diatas mentunjukkan bahhwa mayoritas mekanisme koping lansia di wilayah kerja Puskesmas Rejosari Mempunyai Mekanisme Koping yang Adaptif sebanyak 36 responden (80.0\%). Dan mayoritas tingkat kecemasan lansia di 
wilayah kerja Puskesmas Rejosari Memiliki yaitu Kecemasan Ringan sebanyak 29 responden $(64.4 \%)$ belajar dan mencapai tujuan. Kategori yang termaksud adalah berbicara dengan orang lain, memecahkan masalah secara efektif, teknik relaksasi, latihan seimbang dan

abel 3. Hubungan Mekanisme Koping Dengan Tingkat Kecemasan Lansia Pada Masa Pandemi

Covid-19 di Wilayah Kerja Puskesmas Rejosari Pekanbaru

Tahun 2021

\begin{tabular}{cccccccc}
\hline & & \multicolumn{3}{c}{ Tingkat Kecemasan } & & \multirow{2}{*}{ No } & Mekanisme \\
\cline { 3 - 7 } & Koping & $\begin{array}{c}\text { Kecem as an } \\
\text { Ringan }\end{array}$ & $\begin{array}{c}\text { Kecem as an } \\
\text { Sedang }\end{array}$ & $\begin{array}{c}\text { Kecem as an } \\
\text { Berat }\end{array}$ & & $\begin{array}{c}\text { T } \\
\text { Value }\end{array}$ \\
\hline $\mathbf{l}$ & Adaptif & 26 & 9 & 1 & 36 & 80,0 & \\
$\mathbf{2}$ & Maladaptif & 3 & 4 & 2 & 9 & 20,0 & $\mathbf{0 , 0 3 5}$ \\
\hline & Total & 29 & 13 & 3 & 45 & 100 & \\
\hline
\end{tabular}

Berdasarkan tabel diatas menunjukkan bahwa bahwa dari 36 responden yang memiliki mekanisme koping adaptif terdapat 26 $(57,8 \%)$ responden memiliki Kecemasan Ringan, 9 (20,0\%) responden memiliki Kecemasan Sedang dan 1 (2,2\%) responden yang memiliki Kecemasan Berat. Sedangkan 9 responden yang memiliki mekanisme koping mal adaptif terdapat $3 \quad(6,7 \%)$ responden memiliki kecemasan ringan, 4 $(8,9 \%)$ responden memiliki kecemasan sedang, dan $2(4,4 \%)$ responden memiliki kecemasan berat.

Berdasarkan uji statistic dengan menggunakan chi-square pada tabel 2X3 maka uji yang dipakai adalah Pearson Chi Squere yaitu menunjukkan bahwa $p$ value $=$ 0.035 (< 0.05), dapat disimpulkan bahwa adanya hubungan antara Mekanisme Koping Dengan Tingkat Kecemasan pada masa pandemi Covid-19 di wilayah kerja Puskesmas Rejosari Pekanbaru.

Mekanisme koping merupakan cara yang digunakan individu dalam menyelesaikan masalah, mengatasi perubahan yang terjadi dan situasi yang mengancam baik kognitif maupun perilaku. Mekanisme koping berdasarkan penggolongannya dibagi menjadi yaitu mekanisme koping adaptif yang mendukung fungsi integrasi, pertumbuhan, aktivitas kontruksi (Kusyanti, E. D, 2018)

Mekanisme koping maladaptif merupakan mekanisme koping yang menghambat fungsi integrasi memecah pertumbuhan, menurunkan otonomi dan cenderung menguasai lingkungan. Kategori yang termaksud adalah makan berlebihan atau tidak makan, bekerja berlebihan dan menghindar. (Kusyanti, E. D. 2018).

Hal ini sejalan dengan penelitian yang dilakukan Kusyanti, E. D. (2018). dengan judul penelitian " Hubungan mekanisme koping dengan tingkat kecemasan pasien gagal ginjal kronik yang menjalani hemodialis di RSUD wates" dengan hasil dengan hasil menunjukkan bahwa mekanisme koping adaptif sebanyak 27 responden $(81,8 \%)$.

Pada penelitian ini sebagaian besar responden menggunakan mekanisme koping adaptif. Responden yakin dan optimis dengan masa depan, dengan harapan akan pulih dari virus Covid-19, aktivitas kembali normal. Berbicara dengan orang lain, dan mendapatkan dukungan sosial. Corona virus merupakan sekelompok virus yang menyebabkan sakit pada sistem saluran pernafasan.

Pandemic Covid-19 adalah salah satu jenis virus yang telah menyebabkan krisis 
kesehatan di dunia. Dampak adanya pendemi covid-19 tidak hanya dalam sisi kesehatan saja namun juga merambah ke dunia pemerintahan, pendidikan, social. Sehingga menimbulkan kecemasan yang dapat menurunkan sistem imun tubuh lansia (Susilo, 2020).

Kecemasan merupakan kekhawatiran yang tidak jelas yang berkaitan dengan perasaan yang tidak pasti. Kecemasan dialami secara subjektif dan dikomunikasikan secara intrapersonal. Kecemasan merupakan respon emosional terhadap penilaian suatu bahaya. Kecemasan yang dialami oleh seseorang dipengaruhi oleh beberapa faktor, antara lain usia, jenis kelamin, tingkat pendidika dan dukungan sosial (Sitohang, R. J., \& Simbolon, I. 2021).

Tingkat kecemasan dibagi menjadi 4 tahapan yaitu kecemasan ringan, kecemasan sedang, kecemasan berat dan panik. Kecemasan adalah respon individu terhadap suatu keadaan tidak menyenangkan dan dialami oleh semua makhluk hidup. Kecemasan merupakan pengalaman emosi dan subjektif tanpa ada obyek yang spesifik sehingga orang merasakan sesuatu perasaan was-was (khawatir) seolah-olah ada sesuatu yang buruk akan terjadi dan pada umumnya disertai gejala-gejala otonomik yang berlangsung beberapa waktu. Respons individu terhadap kecemasan beragam dari kecemasan sampai panik (Lestari, Titik, 2015).

Asumsi Peneliti,Penelitian ini menunjukan hasil tingkat kecemasan lansia di Wilayah Kerja Puskesmas Rejosari Memiliki Kecemasan Ringan sebanyak 29 responden (64.4\%). Tingkat kecemasan ringan dipengaruhi mekanisme koping adaptif. Koping yang adaptif menentukan tingkat kecemasan pada masa pandemi covid-19 lansia. Semakin baik koping yang dilakukan lansia untuk mencengah penyebaran covid-19 dengan melakukan 5M yaitu : Mencuci tangan, memakai masker, menjaga jarak, menjauhi kerumunan, mengurangi mobilitas dan mengikuti vaksinasi. Sehingga dapat menurunkan tingkat kecemasan yang dirasakan lansia akibat penyebaran covid-19. Hal ini menunjukkan bahwa adanya Hubungan Mekanisme Koping dengan Tingkat Kecemasan Lansia Pada Masa Pandemi Covid-19. Semakin baik mekanisme koping yang dilakukan maka, kecemasan seseorang akan semakin rendah.

\section{KESIMPULAN}

Hasil Penelitian didapatkan hasil karakteristik lansia berdasarkan Umur Lansia di Wilayah Kerja Puskesmas Rejosari Pekanbaru berada pada rentang umur 60-70 tahun sebanyak 39 responden $(86.7 \%)$. Dengan jenis kelaman Perempuan sebanyak 29 responden (64.4\%). Dan tingkat pendidikan SD sebanyak 21 responden (46.7\%). Berdasarkan hasil Penelitian dari 36 responden yang memiliki mekanisme koping adaptif terdapat 26 $(57,8 \%)$ responden memiliki Kecemasan Ringan, 9 (20,0\%) responden memiliki Kecemasan Sedang dan 1 (2,2\%) responden yang memiliki Kecemasan Berat. Sedangkan 9 responden yang memiliki mekanisme koping mal adaptif terdapat $3 \quad(6,7 \%)$ responden memiliki kecemasan ringan, 4 $(8,9 \%)$ responden memiliki kecemasan sedang, dan $2(4,4 \%)$ responden memiliki kecemasan berat. Berdasarkan uji statistic dengan menggunakan chi-square, maka uji yang dipakai adalah Pearson Chi Squere yaitu menunjukkan bahwa p value $=0.035(<0.05)$, dapat disimpulkan bahwa adanya hubungan antara Mekanisme Koping Dengan Tingkat Kecemasan.

\section{DAFTAR PUSTAKA}

Akbar, K. R., Wilastiara, E. B., Noviyanti, R., Ardiani, R., \& Sudinadji, M. B. (2021). Analisis Perilaku Masyarakat Selama Pandemic Covid-19 Dan New Normal. JIRA: Jurnal Inovasi Dan Riset Akademik, 2(1), 65-78. https://doi.org/10.47387/jira.v2i1.74

Annisa, D. F., \& Ifdil, I. (2016). Konsep Kecemasan (Anxiety) pada Lanjut 
Usia (Lansia). Konselor, 5(2), 93. https://doi.org/10.24036/0201652648 $\underline{0-0-00}$

Akbar, K. R., Wilastiara, E. B., Noviyanti, R., Ardiani, R., \& Sudinadji, M. B. (2021). Analisis Perilaku Masyarakat Selama Pandemic Covid-19 Dan New Normal. JIRA: Jurnal Inovasi Dan Riset Akademik, 2(1), 65-78. https://doi.org/10.47387/jira.v2i1.74

BPS-Statistics Indonesia.2020. Statistik Penduduk Lanjut Usia 2020.Jakarta. Diah Handayani, Et al. 2020. Penyakit Virus Corona 2019, Vol. 40, No. 2.

Hakim, L. N. (2020). Pelindungan Lanjut Usia Pada Masa Pandemi Covid-19. Perlindungan Lanjut Usia Pada Masa Pandemi Covid-19, XII, 13-18. http://berkas.dpr.go.id/puslit/files/info _singkat/Info Singkat-XII-10-IIP3DI- Mei-2020-243.pdf

Hawari, D., 2011. Manajemen stress, cemas dan depresi. Jakarta: FKUI Press. Ilmiyah, S. (2020, Februari 11). Surotul Ilmiyah - PBNU Menjawab Tantangan

Jalowiec.A., 2001. Jalowiec coping scale overview of JCS 1987 (Revised Version).Well Being: Hope. karimah, efi Zuhrotul. 2018.hubungan mekanisme koping dengan tingkat kecemasan padaa perempuan menoupose. Universitas Jember, Jember

Lestari, Titik. 2015. Kumpulan Teori Untuk Kajian Pustaka Penelitian Kesehatan. Nuha Medika, Yogyakarta.

Lestari,Sri .et al. 2018 Hubungan Mekanisme Koping dengan tingkat kecemasan keluarga pasien di ruang ICU RSUD RAA Soewondo Pati .Karya ilmiah untuk peningkatan kesehatan bangsa

McDowell., 2006. Measuring health: a guide to rating scales and questionnaires.
Notoadmodjo, S. 2012. Metodologi Penelitian Kesehatan. Jakarta: Rineka Cipta. Nur Indah Fitriani. 2020. Tinjauan Pustaka Covid-19: Virologi, Patogenesis, Dan Maanifestasi klinis. Jurnal Medika Malahayati, Volume 4, Nomor 3.

Prawitasari, J. E. (2016). Aspek SosioPsikologis Lansia Di Indonesia. Buletin Psikologi, 2(1), 27-34. https://doi.org/10.22146/bpsi.13240

Ratnawati, Emmelia. 2015. Asuhan Keperawatan Gerontik. Pustaka Baru Press, Yogyakarta

Satuan Tugas Penanggana Covid-19. 2021. Komite Penangganan Covid-19 Dan Pemulihan Ekonomi Nasional. Jakarta Setiadi. 2013. Konsep \& Penulisan Riset Keperawatan, Yogyakarta : Grahaa Ilmu

Sitohang, R. J., \& Simbolon, I. (2021). Hubungan Tingkat Pengetahuan Dan Tingkat Kecemasan Lanjut Usia Terhadap Covid-19. Nutrix Journal, $5(1)$, 56. https://doi.org/10.37771/nj.vol5.iss 1.5 $\underline{40}$

Sirait, Healthy Seventina. Et al. 2020. Hubungan penngetahuan tentang covid-19 terhadap tingkat kecemasan pada lansia yang mengalami hipertensi . Jurnal Kesehatan . Vol. 11 No. 2.

Spielberg. C. D., Gorsuch. R.L., Luschene.R., and Jacobs. G. A., 1983. State trait anxiety inventory for adults consulting psychologist. Canada: Press Inc

Sunaryo. 2017. Psikologi Untuk Keperawatan: Edisi 2. Penerbit Buku Kedokteran EGC, Jakarta

Sya'diah, Hidayatus. 2018. Keperawatan Lanjut Usia: Teori dan Aplikasi. Indomedia Pustaka, Sidoarjo

Tinggi, S., Kesehatan, I., Minropa, A., Gadang, S., Padang, K., \& Barat, S. (2020). Faktor yang berhubungan 
dengan tingkat kecemasan lansia pada masa pandemi covid 19. 12(4), 10791088.

Wardaningsih, Shanti \& Nurul Hidayah. 2008. Keperawatan Jiwa.Universitas Muhammadiyah Yogyakarta, Yogyakarta.

Wahyuni, Indri.et al. 2020. Hubungan tingkat religiusita dengan tingkat kecemasan mahasiswa di masa pandemic Covid-19. Jurnal Kesehatan Al- Irsyad Vol XIII.

WHO,2020

https://www.who.int/emergencies/dis eases/novelcoronavirus2019/question-and-answers-hub/q-adetail/coronavirus-disease- covid-19\# 